\title{
血液透析患者における大腸隆起性病変の検討
}

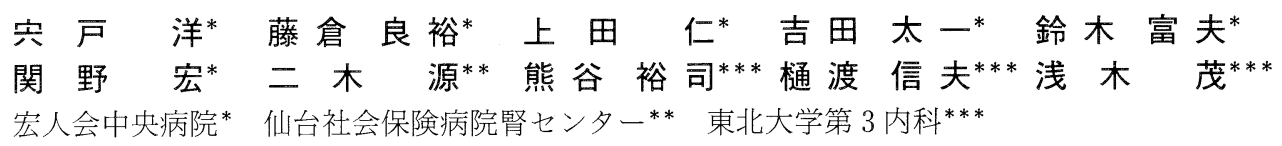

key words：血液透析患者，悪性腫瘍，大腸癌，大腸腺腫

〈要旨〉

近年, わが国では大腸癌の増加傾向が著しく，乥の原因として食生活の欧米化，摂取線維量の減少などがあげられ ている. 透析患者の食生活は高蛋白, 高脂肪食の傾向が強く, 野菜, 果物などの摂取不足になり易い特徵をもってい 当。

今回，我々はこれまでに行った透析患者における下部消化管の検査において発見した大腸隆起性病変に検討を加え $\therefore$.

1981 年 9 月から 1986 年 6 月までに宏人会中央病院で大腸のX線および内視鏡検査を行った維持透析患者数は 81 例（男性 55 例，女性 26 例）である。 その結果，1．大腸隆起性病変を 27 例に 46 病変発見した。大腸癌は 6 例， 8 病変であった。并のうち 3 例は進行癌で外科手術を行った。2.大腸ポリープ例，13 例 (20病変)に内視鏡的ポリペ クトミーを，2 例 (2 病変) に外科的ポリペクトミーを行った。产の結果，3例で早期癌を発見した。内視鏡的ポリ ペクトミー後 3 例で後出血をみたが保存的に止血しえた。内視鏡検査中 1 例で穿孔し緊急手術を行った．３．大腸腺 腫を 19 例に 28 病変発見した。 うち 21 病変は $5 \mathrm{~mm}$ 以上であった。. 4 . 大腸癌および $5 \mathrm{~mm}$ 以上の腺腫例計 18 例 は 50 歳以上が多く, また, 4 年以上の長期透析例が多かった。検査の契機は肛門出血や血便の例が 9 例を占めた。 5. 大腸隆起性病変 (癌, 腺腫, 平滑筋腫, 組織未確認) 計 46 病変の占居部位は $S$ 状結腸が 12 病変 (26\%), 直腸 10 病 变 (22\%) で下部大腸で 48\%を占めた。

以上から, 透析患者では大腸隆起性病変が多く, 出血で発見されている例が多いので, 問診, 直腸指診とともに積 極的な下部消化管の検査が重要であるといえる。 また, 透析患者では便秘例が多く, 低線維, 高脂肪食の傾向が強い ので, 大腸癌の発生に留意する必要があると考えた。

透析患者が大腸癌のハイリスクグループといえるかどうかはさらに症例数を重ねた検討を要する.

\section{Elevated lesions of the colon and the rectum in hemodialysis patients}

Yo Shishido, M. D.*, Yoshihiro Fujikura, M. D.*, Hitoshi Ueda, M. D.* Taichi, Yoshida, M. D.*, Tomio Suzuki, M. D.*, Hiroshi Sekino, M. D.*, Gen Futaki, M. D.**, Yuji Kumagai, M. D.***, Nobuo Hiwatashi, M. D. ${ }^{* * *}$ and Shigeru Asaki, M. D.***

Kojin-kai Central Hospital* ; Renal Unit, Sendai Shakaihoken Hospital** ; The Third Department of Medicine, Tohoku University School of Medicine***

In recent years, the occurrence of colo-rectal cancer has increased markedly in Japan because of the westernization of dietary regimens and a decrease in dietary fiber intake. Hemodialysis patients usually receive high-protein and high-fat diets and they tend not to eat enough vegetables and fruits. The present study deals with elevated lesions of the colon and the rectum in hemodialysis patients detected by examination of the lower digestive tract. Roentogenological and endoscopic examinations of the colon and the rectum were conducted in 81 patients on maintenance hemodialysis (55 males, 26 females) from September 1981 to June 1986 at Kojin-kai

宍戸 洋 宏人会中央病院

干 980 仙台市東七番丁 84 (022-297-6211) 
Central Hospital. The results are as follows : 1 ) Elevated lesions of the colon and the rectum appeared in 27 patients (46 lesions). Eight colo rectal cancers appeared in 6 patients, three of whom underwent surgical operation because of advanced cancer. 2) Thirteen patients (20 lesions) had endoscopic polypectomies and 2 patients (2 lesions) had surgical polypectomy of colo-rectal polyp. Early cancer was found in 3 of these patients. Postpolypectomic hemorrhage, which occurred in 3 patients, was controlled by conservative therapies. Perforation due to endoscopy occurred in 1 patient during the examination and a surgical operation was performed immediately.

3 ) Twenty-eight colo-rectal adenomas were found in 19 patients. Of these, 21 were larger than $5 \mathrm{~mm} .4$ ) Most of eighteen patients with colo-rectal cancer, as well as adenoma over $5 \mathrm{~mm}$ in size, were over 51 years of age and had been maintained on hemodialysis for longer than 4 years. The examination were initiated in 9 patients because of anal hemorrhage or blood in the feces. 5 ) There were forty-six lesions of the colon and the rectum, involving carcinoma, adenoma, leiomyoma and non-identifiable tissue. Twenty-two (48\%) were located in the lower colon ; 12 (26\%) in the sigmoid colon; and 10 (22\%) in the rectum. Elevated lesions of the colon and the rectum, which are detected by hemorrhage, occur frequently in hemodialysis patients. Therefore, examination of the lower digestive tract, as well as careful history-taking and digital examination of the rectum are important in these patients. Since dialysis patients usually take low-fiber and high-fat diets and tend to be constipated, special attention should be paid to the occurrence of colo-rectal cancer. A further study is needed to determine whether hemodialysis patients carry a high risk of colo-rectal cancer.

\section{緒言}

近年，わが国では大腸癌の増加傾向が著しく，その原 因として食生活の欧米化，食物由来の線維の摂取量の減 少などがあげられている ${ }^{1)}$. 一方, 透析患者の食生活は高 蛋白, 高脂肪食が主体であり, 野菜, 果物などの摂取不 足になりやすい特徵がある.

我々は 1981 年 9 月から 1985 年 11 月までに透析患者 の大腸癌症例を 5 例と高頻度に経験したことから, “透析 患者と大腸癌”に関する問題について主として透析患者 の食事面での特徵や便秘などの観点から検討を加え報告 してきた ${ }^{2,3}$. 我々はその後もさらに症例を重ね, 現在ま でに大腸検査を行った例は 81 例を数えているが,さらに 1 例の大腸癌を発見し, 多数の大腸腺腫例も経験してい る.

今回はこれまでに行った透析患者の下部消化管検査で 経験した癌，腺腫例について検討するとともに若干の文 献的考察を加え報告する.

\section{対象・方法}

宏人会で 1981 年 9 月から 1986 年 6 月までの期間に, 大腸の X線透視および内視鏡検查を行った維持透析患者 数は 81 例あり，そのうち男性が 55 例で平均年齢 $55.8 \pm$ 13.1 歳, 女性は 26 例で平均年齢 $55.8 \pm 12.5$ 歳であっ た.このうち 21 例に対しては注腸X線検査のみを, 11 例 に対しては S 状結腸ファィバースコープのみを, 49 例に 対してはX線検查と内視鏡検查の併用を行った.

\section{検討事項}

1. 81 症例において大腸検査を行うに至った理由を 検討した。
2. 発見された大腸隆起性病変 (癌, 腺腫, 平滑筋腫) の性状, 大きさ, 発生部位, その転㷌などの検討を行っ た。大腸ポリープの大きさはポリペクトミーを行ったも のはその回収標本の計測による最大径で，その他はX線 上で計測した。内視鏡で発見されたがX線的に病変を描 出できなかった小病変は内視鏡的にその抒抒よその大き さを判定した。なお，今回の検討では過形成性ポリープ は対象から除外した。

3 . 対象患者の年齢, 透析歴, 検查理由を検討し, 大 腸癌・ $5 \mathrm{~mm}$ 以上の腺腫例の特徵について考察した.

\section{成績}

1. 検查施行理由について

血便や腹痛などの症状があったため検査を行った。な かでも出血（肛門出血，血便，下血）例が 21 例（26\%） と多く, 腹痛は 15 例, 貧血 13 例, 便通異常 11 例等であっ た. 1984 年以後は腹水や体重減少などがみられ悪性腫瘍 の存在が疑われた例や，無症状であっても検診の一環と して検査を行った例が増加している（表 5 ）。

2 . 発見された大腸隆起性病変の検討

発見された大腸隆起性病変は 27 例, 46 病変あった. 大 腸癌は 6 例・ 8 病変であり, うち 3 例は進行癌で外科手 術を行った. 13 例 (20 病変) に内視鏡的ポリペクトミー を，2例（2病変）に外科的ポリペクトミーを行った。 その結果 3 例の早期癌を発見した。 大腸腺腫を 19 例に 28 病変発見した。腺腫の病理組織学的診断は手術, ポリ ペクトミー標本で確認したが， 6病変は生検診断をもつ て行った。1例は平滑筋腫であった。組織未確認のもの は 8 病変 $(6$ 例) で現在経過観察中である. 


\begin{tabular}{|c|c|c|c|c|c|c|c|c|}
\hline 症例 & 年齢 & 性別 & 部位 & 治 & 療 & Dukes 分類 & 深達度 & 備 \\
\hline 1 & 53 & 男性 & $\begin{array}{l}\text { 上行結腸 } \\
\text { 横行結腸 }\end{array}$ & 手 & 術 & $\begin{array}{l}\text { Dukes B } \\
\text { Dukes A }\end{array}$ & $\begin{array}{c}\mathrm{s} \\
\mathrm{m}\end{array}$ & $\begin{array}{l}\text { 横行結腸 Cancer in adenoma（8 mm 亜有茎性） } \\
\text { 大腸腺腫 } 11 \mathrm{~mm} \text { 垔有茎性 } \\
2 \text { 年後，下行結腸に癌 }\end{array}$ \\
\hline 2 & 76 & 女性 & 直 腸 & 手 & 術 & Dukes B & ss & 術後合併症で死亡 \\
\hline 3 & 48 & 女性 & S 状結腸 & 手 & 術 & Dukes C & si & $\begin{array}{l}\mathrm{S} \text { 状結腸, 大腸腺腫 } 14 \mathrm{~mm} \\
\text { 半年後, 下行結腸にポリープ, 横行結腸に tumor }\end{array}$ \\
\hline 4 & 60 & 男性 & 上行結腸 & 内視鏡的ポリ & Jペクトミー & & $\mathrm{m}$ & $\begin{array}{l}10 \mathrm{~mm} \text { (亜有茎性) Cancer in adenoma } \\
4 \text { 年前, S 状結腸, 大腸腺腫 } 16 \mathrm{~mm} \rightarrow \text { ポリペクトミー } \\
\text { 横行結腸, 下行結腸, S 状結腸, 直腸に大腸腺腫 } \\
(3 \text { 個をポリペクトミー) }\end{array}$ \\
\hline 5 & 55 & 男性 & 直 腸 & 内視鏡的ポリ & リペクトミー & & $\mathrm{sm}$ & $\begin{array}{l}18 \mathrm{~mm} \text { 亜有茎性 adenoma in cancer } \\
\text { 後出血 }\end{array}$ \\
\hline 6 & 67 & 男性 & 直 腸 & 内視鏡的ポリ & ノペクトミー & & $\mathrm{m}$ & $\begin{array}{l}7 \mathrm{~mm} \text { 垔有莰性 cancer in adenoma } \\
\text { 上行結腸，直腸に小ポリープ (腺腫) }\end{array}$ \\
\hline
\end{tabular}

表 1 大腸癌症例（1981.9 1986.6）

\begin{tabular}{|c|c|c|c|c|c|c|c|c|c|c|c|}
\hline 症例 & 年齢 & 性別 & 病 変 & 性 状 & -4 & $\begin{array}{l}\text { 大きさ } \\
5 \sim 9\end{array}$ & $\begin{array}{l}(\mathrm{mm}) \\
10 \sim 15\end{array}$ & $16 \sim$ & 診断方法 & 占居部位 & 備 考 \\
\hline 1 & 46 & 男性 & 大腸腺腫 & 有茎性 & & & & 18 & 内視鏡的ポリペクトミー & 下行結腸 & \\
\hline 2 & 52 & 男性 & $\begin{array}{l}\text { 大腸腺腫 } \\
\text { 大腸腺腫 }\end{array}$ & $\begin{array}{l}\text { 有茥性 } \\
\text { 亜有茎性 }\end{array}$ & & 9 & 12 & & $\begin{array}{l}\text { 内視鏡的ポリペクトミー } \\
\text { 内視鏡的ポリペクトミー }\end{array}$ & $\begin{array}{l}\mathrm{S} \text { 状結腸 } \\
\mathrm{S} \text { 状結腸 }\end{array}$ & 後出血 \\
\hline 3 & 55 & 女性 & 大腸腺腫 & 有茎性 & & & 11 & & 外科的ポリペクトミー & 下行結腸 & 胆石手術 \\
\hline 4 & 58 & 女性 & 大腸腺腫 & 亜有莰性 & & & 10 & & 内視鏡的ポリペクトミー & S 状結腸 & \\
\hline 5 & 64 & 男性 & $\begin{array}{l}\text { 大腸腺腫 } \\
\text { 大腸腺腫 } \\
\text { 大腸腺腫 }\end{array}$ & $\begin{array}{l}\text { 哑有茎性 } \\
\text { 严有茎性 } \\
\text { 亜有茎性 }\end{array}$ & & $\begin{array}{l}5 \\
5\end{array}$ & 10 & & $\begin{array}{l}\text { 内視鏡的ポリペクトミー } \\
\text { 内視鏡的ポリペクトミー } \\
\text { 内視鏡的ポリペクトミー }\end{array}$ & $\begin{array}{l}\text { S 状結腸 } \\
\text { 直 腸 } \\
\text { 直 腸 }\end{array}$ & 後出血 \\
\hline 6 & 43 & 男性 & 大腸腺腫 & 亜有茎性 & & 8 & & & 内視鏡的ポリペクトミー & 横行結腸 & \\
\hline 7 & 47 & 男性 & $\begin{array}{l}\text { 大腸腺腫 } \\
\text { 大腸腺腫 }\end{array}$ & $\begin{array}{l}\text { 有茎性 } \\
\text { 無茎性 }\end{array}$ & $\bigcirc$ & 8 & & & $\begin{array}{c}\text { 内視鏡的ポリペクトミー } \\
\text { 生 検 }\end{array}$ & $\begin{array}{l}\text { 下行結腸 } \\
\text { 下行結腸 }\end{array}$ & \\
\hline 8 & 67 & 男性 & 大腸腺腫 & 亜有茎性 & & 7 & & & 外科的ポリペクトミー & 下行結腸 & 穿孔 緊急手術 \\
\hline 9 & 71 & 男性 & 大腸腺腫 & 有茎性 & & 6 & & & 内視鏡的ポリペクトミー & 直 腸 & \\
\hline 10 & 61 & 男性 & 大腸腺腫 & 亜有茎性 & & 5 & & & 内視鏡的ポリペクトミー & 下行結腸 & \\
\hline 11 & 41 & 男性 & 大腸腺腫 & 亜有茎性 & & 5 & & & 内視鏡的ポリペクトミー & S 状結腸 & \\
\hline 12 & 75 & 男性 & 大腸腺腫 & 有茎性 & & 0 & & & 生 検 & S 状結腸 & \\
\hline 13 & 51 & 男性 & 大腸腺腫 & 無茎性 & 0 & & & & 生 検 & 回盲部 & \\
\hline 14 & 68 & 女性 & 大腸腺腫 & 亜有茎性 & $\bigcirc$ & & & & 生 検 & 直 腸 & \\
\hline 15 & 36 & 女性 & 大腸腺腫 & 無茎性 & $\bigcirc$ & & & & 生 検 & $\mathrm{S}$ 状結腸 & \\
\hline 16 & 70 & 男性 & - & 亜有茥性 & $\bigcirc$ & & & & (内視鏡) & S 状結腸 & \\
\hline 17 & 49 & 女性 & - & 亜有茎性 & $\bigcirc$ & & & & （内視鏡） & 直 腸 & \\
\hline 18 & 62 & 女性 & - & 亜有茎性 & & $\bigcirc$ & & & (X線) & 回盲部 & \\
\hline 19 & 63 & 女性 & - & 亜有茎性 & & $\bigcirc$ & & & (X線） & 横行結腸 & \\
\hline 20 & 50 & 女性 & - & $\begin{array}{l}\text { 亜有茎性 } \\
\text { 有茎性 }\end{array}$ & & $\stackrel{\bigcirc}{\bigcirc}$ & & & $\begin{array}{l}(\mathrm{X} \text { 線 }) \\
(\mathrm{X} \text { 線 })\end{array}$ & $\begin{array}{l}\text { 上行結腸 } \\
\text { 上行結腸 }\end{array}$ & \\
\hline 21 & 63 & 男性 & $\begin{array}{l}\text { 平滑筋腫 } \\
\text { 平滑筋腫 }\end{array}$ & $\begin{array}{l}\text { 有茎性 } \\
\text { 無茥性 }\end{array}$ & 0 & 7 & & & $\begin{array}{c}\text { 内視鏡的ポリペクトミー } \\
\text { 生 検 }\end{array}$ & $\begin{array}{l}\text { 下行結腸 } \\
\text { 横行結腸 }\end{array}$ & \\
\hline
\end{tabular}

表 2 大腸腺腫とその他の症例（1981.9～1986.2）

\section{1 ）大腸癌症例の検討}

表 1 亿大腸癌症例の年齢, 性別, 発生部位, 治療, Dukes 分類, 深達度を記した。 なお, 大腸癌症例の症例 1 から 症例 5 まではすでに報告している 2,3 .

症例 1 から症例 3 までは進行癌であった。症例 1 は 1983 年 10 月に上行結腸の進行癌で手術を行ったが, 横 行結腸の 2 個の大腸腺腫のうち 1 個に腺腫内癌が発見さ
れた。術後 2 年 7 力月後に血便が出現し, 精查で下行結 腸に新たに腫瘤性病変が指摘され生検で腺癌であったの で再手術に至った。 Retrospective に注腸 X線写真を検 討すると，第 1 回目の術前のX線写真で下行結腸にすで にポリープ様病変の存在が指摘でき, この病変が増大し たものと考えられた。

症例 2 は直腸の Borrman 2 型の進行癌で手術を行っ 


\begin{tabular}{ccccccc}
\hline 年齢 & 男性 & 癌 & 腺腫 & 女性 & 癌 & 腺腫 \\
\hline $20 \sim$ & 1 & & & - & & \\
$30 \sim$ & 5 & & & 3 & & \\
$40 \sim$ & 12 & & 3 & 7 & 1 & \\
$50 \sim$ & 12 & 2 & 1 & 5 & & 2 \\
$60 \sim$ & 17 & 2 & 4 & 7 & & \\
$70 \sim$ & 6 & & 2 & 4 & 1 & \\
$80 \sim$ & 2 & & & - & & \\
\hline 計 & 55 & 4 & 10 & 26 & 2 & 2 \\
\hline
\end{tabular}

表 3 対象患者の年齢分布と癌・腺腫 (5 mm 以上) 例

\begin{tabular}{cccc}
\hline 透析歴 & 例数 & 大腸癌 & 大腸腺腫 \\
\hline $0 \sim$ & 12 & & \\
$1 \sim$ & 10 & & 1 \\
$2 \sim$ & 15 & & 3 \\
$3 \sim$ & 8 & 1 & \\
$4 \sim$ & 9 & & 6 \\
$5 \sim$ & 8 & 1 & 1 \\
$6 \sim$ & 5 & 3 & \\
$7 \sim$ & 3 & & \\
$8 \sim$ & 4 & & \\
$9 \sim$ & 4 & 1 & \\
$10 \sim$ & 2 & & \\
$11 \sim$ & 1 & & \\
\hline 計 & 81 & 6 & 12 \\
\hline 表 4 & 対象患者の透析歴と癌・腺腫
\end{tabular}

(5 $\mathrm{mm}$ 以上) 例

たが術後合併症で死亡した。

症例 3 はS 状結腸癌で亜イレウスのため手術を行った が肝転移がみられた。術後半年後の注腸 X 線検查で横行 結腸に腫瘤性病変が指摘されている。この病変は組織学 的には未確認ではあるが，癌が強く疑われた。この症例 では S 状結腸にも腺腫が合併していた。

症例 4 から症例 6 までは内視鏡的ポリペクトミーによ り判明した早期癌であった。症例 4 は都合 6 個の腺腫が 発見され，うち 5 個を内視鏡的に切除したが，そのうち の 1 個に腺腫内癌が発見された。

2 ）大腸腺腫およびその他の症例

大腸腺腫，平滑筋腫例抢よび組織未確認例の年齢，性 別, 病変の性状, 大きさ, 診断方法, 占居部位を表 2 に 示した.

大腸腺腫は $10 \mathrm{~mm}$ 以上の例が 5 例，5〜9 $\mathrm{mm}$ の例が 7 例であった。

内視鏡的ポリペクトミーを 10 例に行い，9例 12 病変 の腺腫と 1 例の平滑筋腫を発見している. 外科的ポリぺ クトミーを2例で行ったがいずれも腺腫であった。その 他 5 例は生検により腺腫を確認している.

\begin{tabular}{|c|c|c|c|c|}
\hline 症 & 状 & & 大腸癌 & 大腸腺腫 \\
\hline \multirow[t]{3}{*}{ 出血 } & 肛門出血 & 13 & 2 & 2 \\
\hline & 血 便 & 6 & 3 & 2 \\
\hline & 下 血 & 2 & & \\
\hline \multirow[t]{3}{*}{ 便通異常 } & 便 秘 & 2 & & \\
\hline & 下 痢 & 6 & & 1 \\
\hline & 残便感 & 3 & & \\
\hline 腹 痛 & & 15 & & 3 \\
\hline 貧 血 & & 13 & 1 & 1 \\
\hline 発 熱 & & 4 & & 1 \\
\hline \multicolumn{2}{|c|}{ 悪性腫瘍の疑い } & 7 & & \\
\hline \multicolumn{2}{|c|}{ スクリーニング } & 8 & & 1 \\
\hline \multicolumn{2}{|l|}{ 術前検查 } & 2 & & 1 \\
\hline \multicolumn{2}{|c|}{ 計 } & 81 & 6 & 12 \\
\hline
\end{tabular}

表 5 検查施行理由と癌・腺腫

(5 $\mathrm{mm}$ 以上) 例

3 ）大腸検査抒よび内視鏡的ポリペクトミーの偶発症 について

注腸 $\mathrm{X}$ 線検查では偶発症はみられなかったが, 内視鏡 検査では 1 例（大腸腺腫例の症例 8 , 表 2 ) で検查中下 行結腸で穿孔を㧍こし，緊急外科手術を行った。

内視鏡的ポリペクトミーを行った 3 例 (大腸癌の症例 5 と腺腫の症例 2 と症例 5 ) で後出血がみられたが全例 保存的に止血しえた。

なお，血液透析患者の内視鏡的ポリペクトミー後の偶 発症の問題とその対策についての詳細はすでに報告 ${ }^{2)}$ ているのでここでは省略する.

4 ) 対象患者の性，年齢分布と癌，腺腫 (5 $\mathrm{mm}$ 以上) との関係

検查対象患者の性, 年齢分布が表 3 である. 癌, 腺腫 いずれも 40 歳代にもみられていたが 50 歳以上に多かっ た.

$5)$ 対象患者の透析歴と癌・腺腫（5 $\mathrm{mm}$ 以上）との 関係

検查対象患者の透析歷が表 4 である。癌抢よび腺腫は 3 年以上の長期透析例に多かった。

6 ) 検查施行理由と癌・腺腫（5 $\mathrm{mm}$ 以上）との関係

癌・腺腫例は出血を契機に検査を施行したのが 9 例と 半分を占めていたが，胆石の術前検查やスクリーニング などで発見された無症状例もみられた。また，腹痛や発 熱のため検查を行った結果発見された腺腫例は直接の症 状とは無関係と考えられた（表 5 )。

7 ）大腸隆起性病変の占居部位の検討

発見された 46 病変の部位を検討した。直腸 $(R)$ は 10 病変 $(22 \%), \mathrm{S}$ 状結腸 $(\mathrm{S})$ は 12 病変 $(26 \%)$, 下行結 腸 (D) 10 病変 $((22 \%)$, 横行結腸 $(\mathrm{T}) 7$ 病変 $(15 \%)$, 上行結腸 $(\mathrm{A}) 5$ 病変 $(11 \%)$, 回盲部 $(\mathrm{C}) 2$ 病変 $(4 \%)$ 


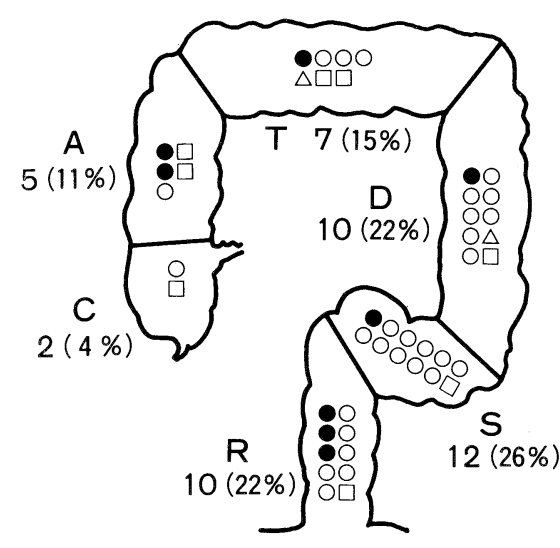

図 1 大腸隆起性病変占居部位 (1981.9 1986.6)

であり，直腸，S状結腸の下部大腸は $48 \%$ を占めた（図 1).

\section{考案}

Matas $\check{5}^{4)}$ の報告以来，透析患者には悪性腫瘍の発生 頻度が高いとの報告が多い。わが国に拉ける報告では透 析患者の悪性腫瘍のうち半分が消化管の癌で，中でも胃 癌の発見頻度業第 1 位を占めている ${ }^{5,6)}$. そ机沛え, 透析 患者に扔ける上部消化管検査の必要性が指摘されその検 診成績の報告 ()もみられている.

一方, 透析患者の直腸癌は一般患者と比較して 2 倍の 発生頻度であり ${ }^{5)}$, Herr ら ${ }^{8)}$ は透析患者で発見された悪 性腫瘍の主要なものとして大腸癌の経験を報告してい る。しかし，これまでに透析患者の大腸癌および腺腫な ど大腸隆起性病変の検討の報告は我々が調べた限り見当 らない。

大腸癌の発生には食事の関連が従来から指摘されてい る。世界各国の脂肪消費量と大腸癌発生率は正の相関を 示して抢り ${ }^{9,10)}$, 高脂肪食により糞便中排泄胆汁酸特に二 次胆汁酸が増え, これが発癌を促進するとの考えや10,11), 食物線維の摂取量が少ない地域では大腸癌の発生率が高 率であり, 線維が少ないほど便秘になりやすく, 腸内容 抢よび粪便の腸内停滞が長く, 腸管と発癌物質との接触 時間が長くなるとの考え ${ }^{12)}$, 摂取食品の違いが腸内細菌 叢への影響を与え, それが大腸内の発癌物質および胆汁 酸を代表とする発癌促進物質の生成, 代謝, 分解に関係 しているとの考え方 ${ }^{13,14)}$ など，多くの報告がある。

透析患者の食生活は最近では自由食をすすめる傾向も あるとはいえ，依然として高脂肪食である。また，便秘 は頑固であることが多く，高カリウム血症対策のため食 物線維の十分な摂取はむずかしいという問題をかかえて いる.
以上の問題を念頭に掞き, 1983 年に第 1 例の大腸癌を 経験して以来, 我々は出血例や腹部症状のあった例に対 して積極的な下部消化管検査を行ってきた。その結果, 大腸癌の 6 例とともに多数の腺腫を発見した。しかし 6 例の大腸癌のうち 3 例が進行癌であり, いずれも痔核か らの出血として臨床的に見逃されていた事実があり患者 指導上反省すべき点があった。透析患者では強い便秘傾 向もあって痔核の合併例も多いことから出血例には直腸 指診や積極的な大腸検查を行い, 下部消化管出血と痔出 血との鑑別診断を正しく行うことが重要と考えた。

近年の大腸癌の早期発見を目的とした大腸集検ではス クリーニング法として便潜血反応検査が導入されてい る.我々の経験した癌, 腺腫例の多くは顕出血例が多かっ たが, 透析患者特有の出血・凝固異常からすると便潜血 反応による非顕出血例のスクリーニングが効率のよい指 標になるものと期待される。特に最近ではヒトへモグロ ビンに特異的に反応する免疫学的便潜血反応 ${ }^{15)}$ が開発さ れ実用化されているので，より精度が高くなると思われ る.

また，病変占居部位の検討では約半数が下部大腸にあ り,下行結腸を含めると $70 \%$ が左側大腸に存在している ので， S 状結腸ファイバースコープのルーチン検査への 導入も有用と考えられる.

大腸癌の発育進展については種々の論議がなされてい る。近年は腺腫内癌の形態をとらずに大腸粘膜から直接 発生した癌一de novo 癌も報告されているが, 腺腫の前 癌病変としての意義は従来から指摘されているところで ある。

以前は $2 \mathrm{~cm}$ 以上の大きな腺腫のみが癌化のポテン シャルが高いという理由で注目されていたが, 最近では $1 \mathrm{~cm}$ 以下の小ポリープにも癌化を示すものが存在する ことがわかり臨床的に無視できえないものとなってい $3^{16)}$. 腺腫から癌への進展は以前は 10 年以上であろうと されてきたが最近ではもっと短いのではないかと考えら れるようになってきた ${ }^{17)}$. 牛尾ら ${ }^{18)}$ の検討でも 5 年以内 の例が約半数を占めておう, 武藤ら ${ }^{199}$ の経験例でも 2 〜 年であり 9 力月という短期間例も報告されている. また, 腺腫は徐々に大きくなるのではなくある時期急に 発育し, 特に腺腫内癌が発育する場合に急速に増大する 可能性が指摘されている ${ }^{17)}$.

今回の検查では多数の腺腫が発見されたが， $5 \mathrm{~mm}$ 以 上の例は 12 例中 11 例が 2 年以上の透析歴を有してお り, うち 8 例は 4 年以上の長期例であった。また, 癌例 のうち 3 例は腺腫共存例であった。さらに進行癌の症例 1 は腺腫内癌を合併し, さらに別の部位に異時性に腺腫 から進展したと思われる癌を併存した多発癌例であっ 
た.また, 症例 3 も多発癌と推察された. 大腸癌例もい ずれも長期透析例であり，すべて 3 年以上，うち 4 例は 6 年以上の透析歴を有していた。

以上のことから, 慢性腎不全一透析導入という内部環 境の変化が, 腺腫の発生あるいは腺腫の癌化に関連して いるのではないかということが問題となる.

透析患者における発癌性についてはこれまでは免疫能 の低下という問題から論じられることが多かった ${ }^{20)}$.

一方, 透析患者では微量元素であるセレニウムが低く, 悪性腫瘍の増加との関連性が検討されている ${ }^{21)}$. セレニ ウムは抗癌作用を示す可能性があり, 大腸癌の発生に対 して予防的ないし抑制的作用を示すとみられている が22), 透析患者のセレニウムは健康人と変わらないとの 報告 ${ }^{23)}$ もりり今後の検討が必要である.

また，透析患者での Ca 代謝異常は周知のことである が，ビタミン D は腸からのカルシウムの吸収を促進し， そのカルシウムが大腸粘膜を保護して大腸癌発生を抑制 する可能性が指摘されている ${ }^{24)}$. 実際アメリカでの 19 年 間の追跡調查でビタミンDの摄取が多くなるにつれて大 腸癌の発生が低下していた事実が報告されている ${ }^{25)}$.

また，透析患者の胃や小腸では発癌性物質であるニト ロソジメチルアミンが多いとの報告がある ${ }^{26)}$. 一般に二 トロソ化合物はヒトの消化管でつくられるので胃癌, 大 腸癌の発生因子のひとつとして注目されている。

以上のように，透析患者では摂取する食事の内容や便 秘の問題の他に，大腸癌発生に関する危険因子が少なか らず存在しているといえる。透析患者に打ける腺腫の発 生, 癌化の問題——透析患者は大腸癌の high risk group なのかどうか一は，さらに多くの症例での下部消化管 検查を積み重衩ていく中で今後明らかになるものと思わ れるが, 透析患者の腸内細菌叢な糞便胆汁酸組成や代謝 の検討, カルシウム代謝異常やニトロソ化合物の存在の 関与などについての検討が必要であると考える。

\section{結語}

1. 血液透析患者 81 例の大腸検査で, 27 例に 46 病変 の隆起性病変を発見した。大腸癌は 6 例, 8 病変, 大腸 腺腫は 19 例, 28 病変であり長期透析にみられた。

2. 肛門出血や血便で発見されている例が多いので, 問診, 直腸指診とともに積極的な下部消化管のX線透視 や内視鏡検査が必要である。

3. 透析患者は便秘例が多く, 低線維, 高脂肪食摂取 の傾向にあるので大腸癌の発生に留意する必要がある。

4. 透析患者に扔ける腺腫, 大腸癌の発生の問題は今 後さらに検討が必要である。

\section{文献}

1）成沢富雄：日本人の食生活の変化と大腸癌. 日本臨 床，39；2022-2027，1981.

2）宾戸 洋, 浅木 茂, 熊谷裕司, 樋渡信夫, 江川春 延, 小林和人, 後藤由夫, 二木 源, 門間弘道, 藤 倉良裕，上田 仁，鈴木富夫，吉田太一，関野 宏： 長期血液透析患者に発見された早期大腸癌の 2 例. 腎と透析，21：441-445，1986.

3）宍戸 洋，浅木 茂，熊谷裕司，樋渡信夫，江川春 延, 小林和人, 後藤由夫, 二木 源, 三浦一章, 岡 崎 肇, 藤倉良裕, 上田 仁, 吉田太一, 鈴木富夫, 関野 宏：血液透析患者に発見された大腸癌症例の 検討。腎と透析，21：769-773，1986.

4) Matas, A. J., Simmons, R. L., Kjellstrand, C. M., Buselmeier, T. J., Naharian, J. S. : Increased incidence of malignancy during chronic renal failure. Lancet, 1 ; 883-886, 1975.

5）山下賀正：透析患者の悪性腫瘍. 大野丞二編, 透析 療法における合併症. p. 69-75, 日本メディカルセン 夕一, 1981 .

6）二木 源, 宍戸 洋, 門間弘道, 上田 仁, 田熊淑 男, 鈴木一之, 北本康則, 石崎 允, 高橋 寿, 三 浦一章, 岡崎 肇, 中村克宏, 藤倉良裕, 関野 宏, 深尾 彰, 浅木 茂: 維持透析患者にみられた悪性 腫瘍例の検討。透析会誌, $19 ； 835-842,1986$.

7）広畑 衛, 長谷川完, 洲崎謹一郎, 大屋 崇：6年 間の維持透析患者胃検診の成績. 透析会誌, 19 ; 739-744, 1986.

8) Herr, H. W., Engen, D. E., Hostetler, J. : Malignancy in uremia: Dialysis versus transplantation. J. Urol., 121 ; 584-586, 1979.

9) Wynder, E. L., Kajitani, T., Ishikawa, S., Dodo, H., Takano, A. : Environmental factors of cancer of the colon and rectum. II. Japanese epidemiological data. Cancer, $23 ; 1210-1220$, 1969.

10) Hill, M. J.: The role of colon anaerobel in the metabolism of bile acids and steroids, and its relation to colon cancer. Cancer, $36 ; 2387-2400$, 1975.

11) Reddy, B.S., Wynder, F. L. : Large-bowel carcinogenesis: fecal constituents of populations with dicerse incidence rates of colon cancer. J. Matl. Cancer Inst., 50 ; 1437-1442, 1973.

12) Burkitt, D. P. : Large-bowel carcinogenesis: an epidemiological jigsaw puzzle. J. Natl. Concer 
Inst., 54 : 3-6, 1975. Aries, V. C., Crowther, J. S., Drasar, B. S. : Bacteria and the aetiology of cancer of the large bowel. Gut, $10: 334-335,1969$.

13) Aries, V. C., Crowther, J. S., Grasar, S. S. : Bacteria and the aetiology of cancer of the large bowel. Gut, 10 ; 334-335, 1969.

14) Hill, M. J., Drasar, B. S., Aries, V. : Bacteria and aetiology of cancer of large bowel. Lancet, I : 95 $-100,1971$.

15）斎藤 博, 土田成紀, 藤田 浩, 福田真作, 相沢 中, 棟方昭博, 吉田 豊：Counter Immunoelectrophor esis を応用した免疫学的便潜血反応に関する研究。 日本消化器病学会誌，79；1944-1949，1982.

16）武藤徹一郎：大腸癌発生の臨床病理。臨時増刊号 癌'82，代謝，19；1201-1214，1982.

17）武藤徹一郎, 安達実樹, 斉藤幸夫 : 発育進展。山村 雄一, 杉村隆監修. 図説臨床〔癌〕シリーズNo.2大 腸癌，p. 119-127，メジカルビュー社，東京，1986。

18）牛尾恭輔, 石川 勉, 笹川道三, 山田達哉, 森谷宣 皓, 北條慶一, 小山靖夫, 板橋正幸, 広田映五, 市 川平三郎：大腸癌, 大腸腺腫の発育経過：X線像に 上る遡及的，時間的検討，消化器外科， 6 ; 1362-1376, 1983.

19）武藤徹一郎，上谷潤二郎，沢田俊夫，小西文雄，草 間 悟, 梅田典嗣, 池田栄一: 臨床的に大腸ポリー プ (腺腫) から癌への変化が観察された 3 症例の報 告. 日消誌，76；1851-1856，1979.

20）吉田栄一, 堀見忠司, 二宮基樹, 岡村孝弘, 平松 聡, 長江聡一, 金田道弘, 向井晃太, 武田 功, 折田薫 三：慢性腎不全患者と免疫能—発癌性に関する臨
床的扔よび基礎的研究——. 透析会誌, $19 ; 447-452$, 1986.

21) Kallistratos, G., Evangelou, A., Seferiadis, K., Vezyraki, P., Barboutis, K. : Selennium and haemodialysis : serum selenium levels in healthy persons, non-cancer and cancer patients with chronic renal failure. Nephron, $41: 217-222,1985$.

22) Jacobs, M. M., Forst, C. F., Beams, F. A. ; Biochemical and clinical effects of selenium on dimethylhydrazine-induced dolon cancer in rats. Cancer Res., 41 ; 4458-4465, 1981.

23) Tsukamoto, Y., Iwamami, S., Marumo, F. : Disburbance of trance element concentrations in plasma of patients with chronic renal fialure. Nephron, 26 ; 174-179, 1980.

24) Newmark, H. L., Wargovich, M. J., Bruce, W. R. : Colon cancer and dietary fat, phosphate, and calcium : A hypothesis. J. Natl. Cancer Inst., 72 ; 1323-1325, 1984.

25) Garland, C., Shekelle, R. B., Barrett-Oonnor, E., Criqui, M. H., Rossof, A. H., Paul, O. : Dietary vitamin $\mathrm{D}$ and calcium and risk of colorectal cancer : A 19-year prospective study in men. The Lancet, Feb., $9:$ 307-308, 1985.

26) Lele, P. S., Dunn, S. R., Simenhoff, M. L., Fiddler, W., Pensabene, J. M. : Evidence for generation of the precardinogen nitrosodimethylamine in the small intestine in chronic renal failure. Kidney Intern. 24 : S 229-223, 1983 